\title{
3 Research Square \\ Gastrointestinal parasitic infection in Gir Cattle (Bos primigenius indicus) and Jaffrabadi Buffalo (Bubalus bubalis) from Junagadh, Gujarat, India
}

Jatin V. Raval ( $\sim$ drjatinraval@gmail.com )

Department of Life Sciences Bhakta Kavi Narsinh Mehta University https://orcid.org/0000-0002-21593613

Riddhi M. Sachaniya

Department of Life Sciences Bhakta Kavi Narsinh Mehta University

\section{Research Article}

Keywords: Gir Cattle, Jaffrabadi Buffalo, Bovine, Gastrointestinal parasites, Junagadh

Posted Date: June 17th, 2020

DOI: https://doi.org/10.21203/rs.3.rs-35376/v1

License: (c) This work is licensed under a Creative Commons Attribution 4.0 International License.

Read Full License 


\section{Abstract}

Coprological analysis was performed to check the presence and previlance of gastrointestinal parasites. One hundred seventy six bovine faecal samples were studied. The study reported the presence of parasitic stages of Balantidium coli, Buxtonella sulcata, Trichostrongylus spp., Toxocara vitulorum, Fasciola spp., Strongyloid spp., and Paraamphistomum spp. $43.51 \%(\mathrm{n}=108)$ faecal samples from Gir cattle (Bos primigenius indicus) were positive for Gastrointestinal parasitic infections. and $36.76 \%$ ( $\mathrm{n}=$ 68) faecal samples from Jaffrabadi Buffaloes (Bubalus bubalis) were positive for Gastrointestinal parasitic infections. In Cattle Balantidium coli was found highest $(20.37 \%)$ and in Buffaloes Buxtonella sulcata was found highest (8.82\%). the highest incidence was recorded during august for both cattle $(6.48 \%)$ and buffalo (7.35\%). Gastrointestinalparasitic infections in claves (< 12 Months) was higher than older (> 60 Months) and adult animals (12-60 Months). Season wise gastrointestinal parasitic infections in cattle were reported maximum (23.15\%) during monsoon. Maximum prevalence in buffalo was reported during Monsoon (16.18\%). similarly, females recorded higher infection rates than malesfor both cattle and buffalo.

\section{Introduction}

Gastrointestinal parasitic infection is a major health problem in domestic animals. Gastrointestinal parasitism is a chief constraint for livestock production leading to heavy economic loss. They have an important impact on the profitability of dairy production systems (Beasley et al., 2010) [5] by affecting the productivity and reproductively of the animals. Gastrointestinal (GI) parasites cause remarkable universal economic losses as a result of digestive disturbance, lowered production, reduced weight gain, impaired reproductive performance, condemnation of affected organs and mortality in infected animals (Raza et al., 2007) [23].

Parasitic diseases caused by intestinal parasites constitute (generate) a major drawback to livestock production (Hosteet al., 2006) [14]. The hot and humid climatic conditions are very native for propagation and perpetuation of parasites (Enderjat, 1964) [10]. Country like India has this kind of climatic conditions throughout the year except three to four months of winter,Therefore, documentation on parasitic prevalence are very necessary to make a suitable plan for its prevention and control (Thakreet al., 2019) [32]. The present communication deals with the prevalence of gastrointestinal (GI) parasites in Gir cattle and Jaffrabadi buffalo of Junagadh.

\section{DETAILS OF THE SPECIES ENCOUNTERED}

In present study total seven species of gastrointestinal parasites were recorded. Out of which two species of phylum Protozoa, two species of phylum Platyhelminthes and three species of phylum Nemathelminthesof Gastrointestinal (GI) parasites were recorded. 


\section{Balantidium coli (Malmsten,1857)}

Balantidiasis caused by Balantidium colicould be emerged as a significant pathogen that is able to cause disease in horses (Headley et al., 2008) [12], buffaloes (Tarrar et al., 2008) [30], cattle (Randhawa et al., 2010) [22] and camels (Abubakr et al., 2000 [1]; AL-Tayib, 2014 [4]; Cox, 2005) [7].

\section{Buxtonella sulcate (Jameson, 1926)}

B. sulcata is a ciliate protozoan inhabiting colon which is considered as an opportunistic $B$. sulcata is considered as an opportunistic ciliate protozoan inhabiting colon of cattle and buffalo (Levine, 1985; [17] Bhatia, 2000) [6].

\section{Toxocara vitulorum (Goeze, 1782)}

T. vitulorum is one of the most common and hazardous intestinal parasite (Woodbury, 2012) [34] which cause anorexia, diarrhoea, weight loss and calf mortality (Roldan et. al., 2010) [25]. Bovine toxocariosis is among the most economically important diseases, affecting animals mainly at young age due to maternal infection, and frequently causing death (Devi et al. 2000) [9].

\section{Trichostrongylus spp. (Looss, 1905)}

In ruminants Trichostrongylus worms are mostly found in mixed infections with other gastrointestinal roundworms. Trichostrongylus worms damage the lining of the small intestine or the stomach of the host, which can lead to enteritis, gastritis, and sometimes anemia as well (Junquera, 2017/ parasitepedia.net) [15].

\section{Strongyloids spp. (Grassi, 1879)}

Strongyloides is a parasite of world-wide distribution that can remain dormant for many years in the intestine, and then cause a devastating syndrome of disseminated strongyloidiasis (Gelberg, 2017) [11].

\section{Fasciola spp. (Linnaeus, 1758)}

Fasciolosis is important food born and water born parasitic zoonosis caused by liver fluke of the genus Fasciola. Fascioliasis, a serious infectious parasitic disease infecting domestic ruminants and humans, tops all the zoonotic helminthes worldwide (Mas-Coma et.al., 2005) [19].

\section{Paramphistomum spp. (Fischoeder, 1901)}

Paramphistomum flukes are also called rumen flukes or stomach flukes (source: parasitepedia.net) [29]. Adult Paramphistomes are the main parasites in the rumen and reticulum of sheep, goats, cattle and water buffaloes (Al-Gaabary, 2009) [3].

\section{Materials And Methods}


Faecal samples of cattle and buffaloes were collected from Junagadh region. The samples were examined in the laboratory by sedimentation and floatation technique (Soulsby, 1982) [28]. A total of 176 (108-Gir cattle \& 68-Jaffrabadi buffalo) faecal samples were collected from selected sites i.e. farms and cowshed (Gaushala) of Junagadh area from period August, 2019 to March, 2020. Freshly dropped faecal samples were collected for parasitological examination. Approximately $40 \mathrm{~g}$ faeces were collected into individual zipper storage bags or plastic pots with label. Collected samples were stored with ice bags until examined.The samples were examined for parasitic eggs and protozoan ova/oocystwith 10x and 40x magnification of compound microscope(Zajac and Conboy, 2012) [35], (Hendrix et al., 2006) [13].

\section{Result And Discussion}

The present study was conducted to know the month, season, sex, age and species wise prevalence (\%) of gastrointestinal parasites in Gir Cattle and Jaffrabadi Buffalo in Junagadh area. Samples were collected from August-2019 to March-2020. The incidence of diversified GI parasites encountered in this study in cattle and buffaloes are summarized in [Table 1]. Microscopic examination exposed that (43.52\%) faecal samples from cattle were positive for GI parasitic infections. And (36.76\%) faecal samples from buffaloes were positive for GI parasitic infections. The highest load of GI parasites was recorded during august (wet month) in both cattle (23.15\%) and buffalo (16.18\%). According to (Degefu et al., 2011) [8] the overall prevalence of GI helminths infection was higher in October (wet month) and lower in February, reason for this could be conducive environment for the development of larvae.

The different species of GI parasites which were found after examination of faecal samples has been represented in [Table 2]. Species wise prevalence showed the presence of seven species of different parasite (eggs/ova/cysts). Out of it two species are of protozoa (Ciliate) viz.Balantidiumcolin cattle (20.37\%) and buffalo (8.82 \%) and Buxtonella sulcata in cattle (9.26\%) and buffalo (16.18\%). This was in close agreement with (Singh, 2014) [27] and (Nath et al., 2016) [20] who recorded Balantidium Coli as dominant protozoa. Though, Buxtonella sulcata and Balantidiumcoliare considered as non-pathogenic protozoa, recently many researchers had reported its pathogenicity leading to diarrhoea (Al-Saffar et al. 2010) [2]. The lower prevalence of trematodal infections (amphistomosis and fasciolosis) recorded is mainly because of the occurrence that the animals of Junagadh region are mostly stall fed thus decreasing the chances of exposure to the infective intermediate host present on the vegetation in the vicinity of water bodies (Maharana et al., 2016) [18].

It was observed studied that the age wise prevalence of GI parasitic infection was highest in young cattle $(23.15 \%)$ than old $(12.96 \%)$ and adults $(7.41 \%)$. Highest incidence was recorded in young buffalo (14.71) than old (13.24) and adults (8.82). [Table 3]. The prevalence of GI parasites with the age has also been reported by Quershi and Tanveer (Quershi and Tanveer, 2009) [21] and (Telila et al., 2014) [31]. On the contrary, Regassaet al., 2006 (Regassaet al., 2006) [24] stated that the younger animals are more susceptible than adult animals. Age wise percentage (\%) based on species is summarised in [Fig 1]. 
Regarding over all sex wise prevalence, though positive ratio of gastrointestinal parasitic infection was higher in female cattle than male $(32.41 \%$ vs $11.11 \%)$ and a similarly observed for buffaloes $(29.85 \%$ vs $7.46 \%$ ), [Table 4] This findings can be supported by the fact that this region of Gujarat usually shows common managemental practices that are adopted for animals of both male and female followed by deworming programme which is similar for each that give reason of being no significant difference in prevalence of parasitic infections among males and females could be detected (Maharana et al., 2016) [18]. Sex wise percentage (\%) based on species is summarised in [Fig 2].

Season wise prevalence (\%) of GI parasitic infections in Gir cattle \& Jaffrabadi buffalo is presented in [table 5]. In present study, maximum prevalence in cattle was reported during monsoon $(23.15 \%)$ followed by Post monsoon (12.04 \%), winter (7.41\%) and summer (0.93\%). Maximum prevalence in buffalo was reported during Monsoon (16.18\%) followed by Post monsoon (11.76 \%), winter (7.35\%), and summer $(1.47 \%)$. As well as minimum prevalence was reported during Summer in cattle $(0.93 \%)$ and buffalo $(1.47 \%)$. The reason for highest prevalence of $\mathrm{Gl}$ parasitic infections during monsoon is High moisture content along with temperature prevailed during rainy season favours the growth and development of larvae, as also observed in earlier studies carried out by various researchers (Lahaet al., 2013) [16], (Vanisriet al., 2016) [33] and (Shit et al., 2017) [26].

The overall phylum wise incidence of parasitic infections in both cattle and buffalo is given in [Fig 3]. Highest incidence (68\%) was recorded in phylum Protozoa followed by Nemathelminthes (23\%) and Platyhelminthes (9\%).

Table 1: Month wise incidence (\%) of GI parasitic infections in Gir Cattle \& Jaffrabadi buffalo.

\begin{tabular}{|l|l|l|l|l|l|l|}
\hline \multirow{2}{*}{ Month } & \multicolumn{4}{|l}{ Cattle (n=108) } & \multicolumn{3}{l|}{ Buffalo (n=68) } \\
\cline { 2 - 7 } & Samples examined & No. infected & $\begin{array}{l}\text { Incidence } \\
(\%)\end{array}$ & $\begin{array}{l}\text { Samples } \\
\text { examined }\end{array}$ & No. infected & $\begin{array}{l}\text { Incidence } \\
(\%)\end{array}$ \\
\hline Aug-19 & 38 & 25 & 23.15 & 26 & 11 & 16.18 \\
\hline Sep-19 & 9 & 7 & 6.48 & 9 & 4 & 5.88 \\
\hline Oct-19 & 9 & 3 & 2.78 & 7 & 3 & 4.41 \\
\hline Nov-19 & 10 & 3 & 2.78 & 6 & 1 & 1.47 \\
\hline Dec-19 & 8 & 4 & 3.70 & 6 & 3 & 4.41 \\
\hline Jan-20 & 11 & 2 & 1.85 & 4 & 1 & 1.47 \\
\hline Feb-20 & 10 & 2 & 1.85 & 2 & 1 & 1.47 \\
\hline Mar-20 & 13 & 1 & 0.93 & 8 & 1 & 1.47 \\
\hline Total & 108 & 47 & 43.52 & 68 & 25 & 36.76 \\
\hline
\end{tabular}

Table 2: Species wise incidence (\%) of GI parasitic infections in Gir Cattle \& Jaffrabadi buffalo. 


\begin{tabular}{|l|l|l|l|l|}
\hline \multirow{2}{*}{ Parasite } & \multicolumn{2}{|l|}{ Cattle (n=108) } & \multicolumn{2}{l|}{ Buffalo (n=68) } \\
\cline { 2 - 5 } & No. infected & Incidence (\%) & No. infected & Incidence (\%) \\
\hline Balantidium coli & 22 & 20.37 & 6 & 8.82 \\
\hline Buxtonella sulcata & 10 & 9.26 & 11 & 16.18 \\
\hline Fasciola spp. & 2 & 1.85 & 3 & 4.41 \\
\hline Paraamphistomum spp. & 1 & 0.93 & 0 & 0.00 \\
\hline Strongyloid spp. & 3 & 2.78 & 1 & 1.47 \\
\hline Toxocara vitulorum & 2 & 1.85 & 3 & 4.41 \\
\hline Trichostrongylus spp. & 7 & 6.48 & 1 & 1.47 \\
\hline Total & 47 & 43.52 & 25 & 36.76 \\
\hline
\end{tabular}

Table: 3 Overall age wise incidence (\%) of GI parasitic infections in Gir Cattle \& Jaffrabadi buffalo.

\begin{tabular}{|l|l|l|l|l|l|l|}
\hline \multirow{2}{*}{ Total positive } & \multicolumn{2}{|c|}{ Young } & \multicolumn{2}{c|}{ Adult } & \multicolumn{2}{c|}{ Old } \\
\cline { 2 - 7 } & No. infected & Incidence (\%) & No. infected & Incidence (\%) & No. infected & Incidence (\%) \\
& & & & & & \\
\hline Cattle (n=108) & 25 & 23.15 & 8 & 7.41 & 14 & 12.96 \\
\hline Buffalo (n=68) & 10 & 14.71 & 6 & 8.82 & 9 & 13.24 \\
\hline
\end{tabular}

Table: 4 Over all sex wise incidence (\%) of GI parasitic infections in Gir Cattle \& Jaffrabadi buffalo.

\begin{tabular}{|l|l|l|l|l|}
\hline Type & Sex & No. of Sample & No. infected & Incidence (\%) \\
\hline Cattle (n=108) & Male & 22 & & \\
\cline { 2 - 5 } & Female & 86 & 12 & 11.11 \\
\hline \multirow{2}{*}{ Buffalo (n=68) } & Male & 9 & 35 & 32.41 \\
\cline { 2 - 5 } & Female & 59 & 5 & 7.46 \\
\hline
\end{tabular}

Table: 5Season wise incidence (\%) of GI parasitic infections in Gir cattle \& Jaffrabadi buffalo in Junagadh region. 


\begin{tabular}{|l|l|l|l|l|l|l|}
\hline \multirow{2}{*}{ season } & \multicolumn{2}{|l|}{ Cattle (n=108) } & \multicolumn{2}{l|}{ Buffalo (n=68) } \\
\cline { 2 - 7 } & $\begin{array}{l}\text { sample } \\
\text { examined }\end{array}$ & $\begin{array}{l}\text { No. } \\
\text { infected }\end{array}$ & $\begin{array}{l}\text { Incidence } \\
(\%)\end{array}$ & $\begin{array}{l}\text { sample } \\
\text { examined }\end{array}$ & $\begin{array}{l}\text { No. } \\
\text { infected }\end{array}$ & $\begin{array}{l}\text { Incidence } \\
(\%)\end{array}$ \\
\hline Monsoon & 38 & 25 & 23.15 & 26 & 11 & 16.18 \\
\hline Post monsoon & 28 & 13 & 12.04 & 22 & 8 & 11.76 \\
\hline Winter & 29 & 8 & 7.41 & 12 & 5 & 7.35 \\
\hline Summer & 13 & 1 & 0.93 & 8 & 1 & 1.47 \\
\hline Total & 108 & 47 & 43.52 & 68 & 25 & 36.76 \\
\hline
\end{tabular}

\section{Conclusion}

Various gastrointestinal parasites have been found in Gir Cattle and Jaffrabadi buffaloes in Junagadh region were infected with Balantidium coli, Buxtonella sulcata, Fasciola spp., Paraamphistomum spp., Toxocara vitulorum, Trichostrongylus spp. Strongyloid spp. of GI parasites. The present study showed a higher prevalence of GI parasites in cattle $43.52 \%(n=108)$ than in buffaloes $36.76 \%(n=68)$. The prevalence rates of $\mathrm{GI}$ parasites varied with month. Females carried higher GI parasitic burden than males. In young animals (calves - below 1 year) Gl parasitic infection was higher followed by older (more than 5 years) and adults (1-5 years). Seasonal GI parasitic load were maximum in monsoon and post monsoon.

\section{Declarations}

\section{ACKNOWLEDGEMENTS}

The authors are thankful to Animal disease investigation unit Junagadh for providing laboratory facilities to carry out this research. Authors are also thankful to Dr. Jatin M. Sanchaniya for sample collection.

Competing interests: The authors declare no competing interests.

\section{References}

1. Abubakr, M. I., Nayel, M. N., Fadlalla, M. E., Abdelrahman, A. O., Abuobeida, S. A., and Elgabara, Y. M. (2000). Prevalence of gastrointestinal parasites in young camels in Bahrain. Review of Livestock and Veterinary Medicine of Tropical Countries, 53 (3), pp. 267-272.

2. Al-Saffar T. M., Suliman E. G. and Al-Bakri H. S. (2010). Prevalence of intestinal ciliate Buxtonella sulcata in cattle. Mosul Iraqi Journal Veterinary Science 24(1): pp. 27-30.

3. Al-Gaabary, M. H., Osman, S. A., and El-Tonoby, A. G. Studies on Paramphistomiasis In Ruminants.

4. Al-Tayib, O. (2014). Case report zoonotic balantidiasis in camel from Saudi Arabia. Scholar Academic Scientific Publisher, 2(7), pp. 445-447. 
5. Beasley, A. M., Kahn, L. P., and Windon, R. G. (2010). The periparturient relaxation of immunity in Merino ewes infected with Trichostrongylus colubriformis: parasitological and immunological responses. Veterinary Parasitology, 168(1-2), pp. 60-70.

6. Bhatia B. B., (2000). Textbook of veterinary protozoology. $1^{\text {st }}$ Indian Council of Agricubltural Research, Pusa,pp. 336-337.

7. Cox, F. E. (2005). Human balantidiasis in Iran: are camels reservoir hosts. Trends in parasitology, 21(12), p. 553.

8. Degefu, H., Abera, C., Yohannes, M., \&Tolosa, T. (2011). Gastrointestinal helminth infections in smallscale dairy cattle farms of Jimma town, Ethiopia. Ethiopian Journal of Applied Science and Technology, 2(1), pp. 31-37.

9. Devi, H. U., Ansari, M. Z., Singh, S. K., and Devi, K. B. (2000). Prevalence and epidemiology of Toxocara virulorum in cow and buffalo calve in and around Ranchi, Bihar. Indian Journal of Animal Sciences (India), 70(8), pp. 817-819

10. Enderjat E. (1964). Helminths and Helminthiasis in Assam. Indian Veterinary Journal 41, pp. 538542.

11. Gelberg, H. B. (2012). Alimentary system and the peritoneum, omentum, mesentery, and peritoneal cavity. In Pathologic Basis of Veterinary Disease (Zachary, J. F., McGavin, M. D., eds.), 5th edition, Elsevier, St. Louis, MO, USA, pp. 322-404.

12. Headley, S., Kummala, E., and Sukura, A. (2008). Balantidium coli-infection in a Finnish horse. Veterinary parasitology, 158(1-2), pp. 129-132.

13. Hendrix, C., M and Robinson, E. (2006). Diagnostic Parasitology for Veterinary Technicians. 3rd edn., Mosby Inc. of Elsevier Inc. pp. 255-60.

14. Hoste, H., Jackson, F., Athanasiadou, S., Thamsborg, S. M., and Hoskin, S. O. (2006). The effects of tannin-rich plants on parasitic nematodes in ruminants. Trends in parasitology, 22(6), pp. 253-261.

15. Junquera, 2017/ parasitepedia.net, retrieved on 28/02020

16. Laha, R., Das, M., and Goswami, A. (2013). Gastrointestinal parasitic infections in organized cattle farms of Meghalaya. Veterinary world, 6(2), pp. 109-112.

17. Levine N. D (1985). Vet Protozool. lowa State University Press, Ames, pp 334-364.

18. Maharana, B. R., Kumar, B., Sudhakar, N. R., Behera, S. K., and Patbandha, T. K. (2016). Prevalence of gastrointestinal parasites in bovines in and around Junagadh (Gujarat). Journal of parasitic diseases, 40(4), pp. 1174-1178.

19. Mas-Coma, S., Bargues, M. D., and Valero, M. A. (2005). Fascioliasis and other plant-borne trematode zoonoses. International journal for parasitology, 35(11-12), pp. 1255-1278.

20. Nath, T. C., Islam, K. M., Ilyas, N., Chowdhury, S. K., and Bhuiyan, J. U. (2016). Assessment of the prevalence of gastrointestinal parasitic infections of cattle in hilly areas of Bangladesh. World Scientific News, 59, pp. 74-84. 
21. Qureshi, A. W., and Tanveer, A. (2009). Seroprevalence of fasciolosis in buffaloes and humans in some areas of Punjab, Pakistan. Pakistan Journal of Science, 61(2), pp. 91-96.

22. Randhawa, S. N. S., Singla, L. D., and Randhawa, C. S. (2010). Chronic cattle diarrhoea due to Balantidium coli infection-a clinical report. Journal of Veterinary Parasitology, 24(2), pp. 197-198.

23. Raza, M. A., Iqbal, Z., Jabbar, A., and Yaseen, M. (2007). Point prevalence of gastrointestinal helminthiasis in ruminants in southern Punjab, Journal of Helminthology, 81(3), pp. 323-328.

24. Regassa, F., Sori, T., Dhuguma, R., and Kiros, Y. (2006). Epidemiology of gastrointestinal parasites of ruminants in Western Oromia, Ethiopia. International Journal of Applied Research in Veterinary Medicine, 4(1), pp. 51-57.

25. Roldan, W. H., Espinoza, Y. A., Huapaya, P. E., and Jiménez, S. (2010). Diagnosis of human toxocarosis. Peruvian journal of experimental medicine and public health, 27(4), pp. 613-620.

26. Shit, N., Hajra, D. K., Baidya, S., and Debbarma, A. (2017). Seasonal occurrence of gastrointestinal helminth parasites in cattle and buffaloes in Bankura district, West Bengal, India. Exploratory Animal and Medical Research, 7(1), pp. 58-63.

27. Singh, B. (2014). Subclinical Gastrointestinal Parasitoses In Crossbred Cattle (Doctoral dissertation, Rajasthan University of Veterinary and Animal Sciences, Bikaner-334001).

28. Soulsby, E. J. L. (1982). Helminths, arthropods and protozoa of domesticated animals 7th edn. The English Language Book Society and Bailliere Tindall, London, pp. 234-235.

29. source: parasitepedia.net, retrieved on 02/04/2020

30. Tarrar, M. A., Khan, M. S., Pervez, K., Ashraf, K., Khan, J. A., and Rehman, Z. U. (2008). Detection and chemotherapy of Balantidium coli in buffaloes around Lahore, Pakistan. Pakistan J Agr Sci, 45, pp. 163-166.

31. Telila, C., Abera, B., Lemma, D., and Eticha, E. (2014). Prevalence of gastrointestinal parasitism of cattle in East Showa Zone, Oromia regional state, Central Ethiopia. Vet. Med. Anim. Health, 6(2), pp. $54-62$.

32. Thakre, B. K., Kumar, B., Brahmbhatt, N., Parmar, V. L., Patel, J., Damor, J., and Patel, J. A. (2019). Gastrointestinal parasitic infections in cattle and buffaloes in southwestern region of Gujarat, India. Indian Journal of Animal Sciences, 89(7), pp. 31-33.

33. Vanisri, V., Subramanian, N., and Muthu, M. (2016). Prevalence of gastrointestinal parasites in cattle in and around Cheyyar taluk, Thiruvannamalai district. International Journal of Information Research and Review, 3(11), pp. 3282-3294.

34. Woodbury, M., Copeland, S., Wagner, B., Fernando, C., Hill, J. E., and Clemence, C. (2012). Toxocara vitulorum in a bison (Bison bison) herd from western Canada. The Canadian Veterinary Journal, 53(7), p. 791.

35. Zajac, A. M., \& Conboy, G. A. (Eds.). (2012). Veterinary clinical parasitology. John Wiley \& Sons.

\section{Figures}




\section{fig 1}

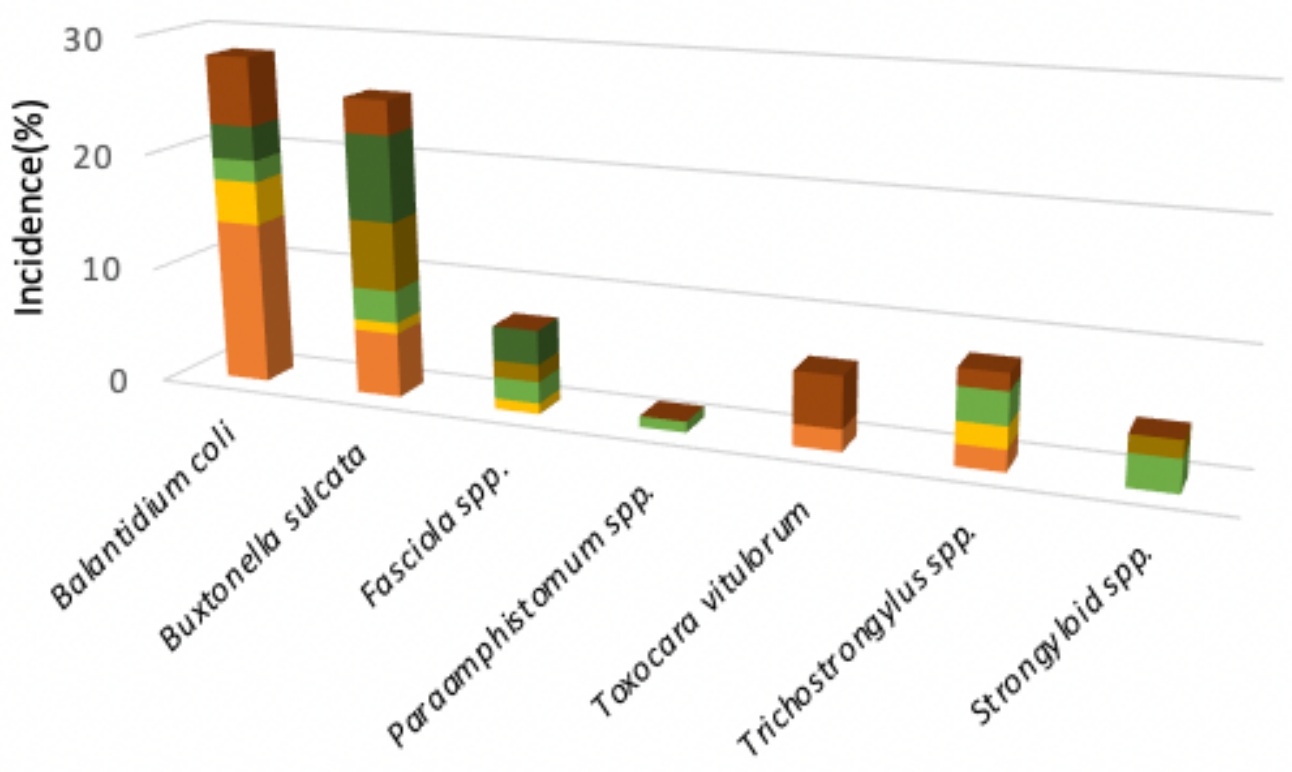

Parasite species

- Cat tle Young \% $\quad$ Cat tle Adult \% $\quad$ Cat tle Old \%

Buffalo Adult \% Buffalo Old \% Buffalo Young \%

\section{Figure 1}

Age wise incidence (\%) based of species of parasites of GI parasitic infections in Gir Cattle \& Jaffrabadi buffalo in Junagadh region. 
fig 2

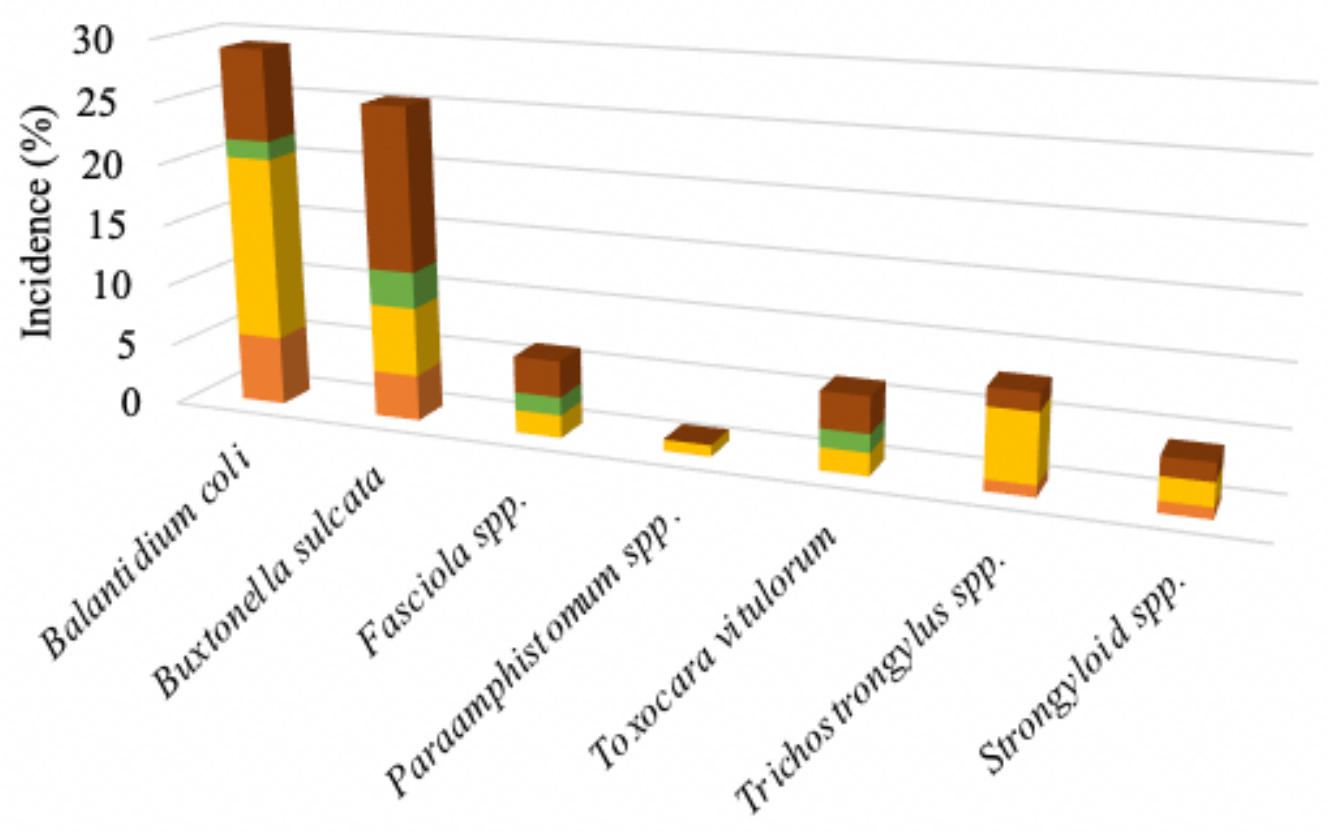

Parasite species

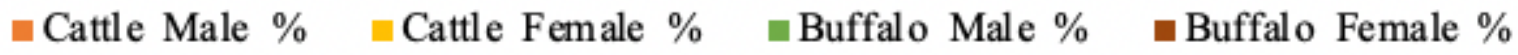

\section{Figure 2}

Sex wise incidence (\%) based on parasite species of GI parasitic infections in Gir cattle \& Jaffrabadi buffalo. 


\section{fig 3}

- Nemathelminthes,

- Platyhelminthes, 6,

$8 \%$ $17,24 \%$

Protozoa $\square$ Platyhelminthes $\square$ Nemathelminthes

\section{Figure 3}

Overall Phylum wise incidence (\%) of Parasite species in Gir cattle and Jaffrabadi Buffalo. 